\title{
Phytochemicals with potential effects in metabolic syndrome prevention and therapy
}

\author{
Andrea Holubkováa ${ }^{\text {, Adela Penesováb }}{ }^{\text {Ernest Sturdik }}{ }^{a}$, \\ Silvia Mošovskáa, Lucia Mikušováa \\ ${ }^{a}$ Department of Nutrition and Food Assessment, Institute of Biochemistry, Nutrition and Health Protection, \\ Faculty of Chemical and Food Technology, Slovak University of Technology, \\ Radlinského 9, 81237 Bratislava, Slovak Republic \\ ${ }^{b}$ Institute of Experimental Endocrinology, Slovak Academic of Science, Vlárska 3, 83306 Bratislava \\ andrea.holubkova@stuba.sk
}

\begin{abstract}
Metabolic syndrome represents a clustering of risk factors related to an elevated danger of cardiovascular diseases and type 2. diabetes. The high incidence of obesity, the key risk factor in metabolic syndrome, and the lack of safe pharmaceutical agents have fuelled an increase in research related to anti-metabolic syndrome drugs. Phytochemicals have biological properties such as antioxidant, modulation of detoxification enzymes, stimulation of the immune system, reduction of platelet aggregation and modulation of hormone metabolism. These compounds include vitamins, comprising of vitamin C, D and E, flavonoids, phenolic acids, omega- 3 and omega- 6 fatty acids. Furthermore, the latest discoveries and studies on the molecular mechanism of these phytochemicals suggested their potential positive effect in the prevention and treatment of obesity and other risk factors associated with the metabolic syndrome. They should be incorporated in food ingredients, dietary supplements, or drug preparations. The main focus of this article is to review the available information on various aspects of phytochemicals, with special reference to their effectiveness in risk reduction of the metabolic syndrome and obesity-related diseases.
\end{abstract}

Keywords: flavonoids, insulin resistance, metabolic syndrome, obesity, phytochemicals, prevention

\section{Introduction}

Nowadays, the metabolic syndrome (MS) represents one of the most serious problems in the developed and also developing countries of the world. This disease constitutes a group of metabolic symptoms and abnormalities, that result and are closely related to today's lifestyle, lack of physical activity, unsuitable nutrition and total regimen. An important fact is that accumulation of risk factors of MS contributes to type 2 . diabetes as well as to very high cardiovascular morbidity and mortality (Balkau et al. 2007, Akitunde and Akinwusi 2011). Therefore, prevention and treatment of each component of MS, become primary task for healthcare organisations in all developed countries.

Abdominal obesity is one of the basic features of MS. In the most European countries, including Slovakia, almost one fifth of the adult population is obese and more than half overweight (Krahulec 2008). We can say that obesity is at the beginning of the complicated cascade of the pathophysiology process of MS.

"The exact etiology of MS remains unclear, but it is complex interactions between genetic, metabolic and environmental factors. Among environmental factors, dietary habits play important role in the prevention and treatment of this condition. Gen- eral recommendations include decreasing obesity rate, increasing physical activity and consume an anti-atherogenic diet focused on low fat intake, food rich on vegetables, fruits and whole grains" (Feldeisen and Trucker 2007).

The medicinal product, which would specifically treat all components of the MS, has not been developed yet. At present, many natural substances are widely used as a preventive therapy. The most numerous group of these substances consists of flavonoids, glucosinolates (isothiocyanates and indoles), phenolic acids, phytates, phytoestrogens (isoflavones and lignans), fats and oils contained in vegetables, fruits, cereals, legumes and other plant sources. Many of these substances are characterized by antimutagenic, anticarcinogenic, antioxidant, antiinflammatory, antiobese, cholesterol lowering and antidiabetic effects (Surh 2002, Surh et al. 2001).

The aim of this review was to summarize the current research of the pathophysiology of MS and phytochemicals as preventive and therapeutic substances in fight against this disease.

\section{Definition of metabolic syndrome}

The term of MS represents a combination of diseases or metabolic abnormalities. They occur together and increase the risk of cardiovascular diseases (CVD) and type 2. diabetes. MS includes abdominal 
obesity, insulin resistance (IR), high blood pressure and dyslipidaemia (Klimeš 1998, Balkau et al. 2007, Akitunde and Akinwusi 2011).

A summary of the causes of IR and its metabolic consequences are shown in Fig. 1 (Klimeš 1998, Reaven 1993).

These four units are also called deadly quartet, they include (Galajda and Mokáň 2006, Galajda and Mokáň 2004):

- obesity

- disorders in carbohydrate metabolism associated with IR such as borderline fasting blood glucose and impaired glucose tolerance

- dyslipidemia characterized by an increased in triglycerides (TAG) content, reduced DHL cholesterol (high density lipoprotein), increased amount of small dense LDL particles (low density lipoprotein), which leads to acceleration of atherosclerosis

- arterial hypertension (HT)

Several terms are used for this set of metabolic abnormalities described above. The most com- mon is metabolic syndrome, insulin resistance syndrome, syndrome $\mathrm{X}$, dysmetabolic syndrome, pluri-metabolic syndrome or Reaven's syndrome (Balkau at al. 2007).

There are a number of diagnostic criteria for a definition of MS. These criteria were proposed by the World Health Organization (WHO), International Diabetes Federation (IDF), National Cholesterol Education Program-NCEP, Adult Treatment Panel-ATP III and European Group for the Study of Insulin Resistance-EGIR (Bray 2007, Balkau at al. 2007). The diagnostic criteria of MS are summarized in Table 1.

Some authors attribute to the insulin resistance syndrome also pathological status called ovarian hyperandrogenism and hirsutism in women, occurring simultaneously with IR and hyperinsulinemia (Klimeš 1998).

\section{Pathophysiology of metabolic syndrome}

Exact mechanisms of MS pathophysiology are not fully known. Known factors that contribute to its de-

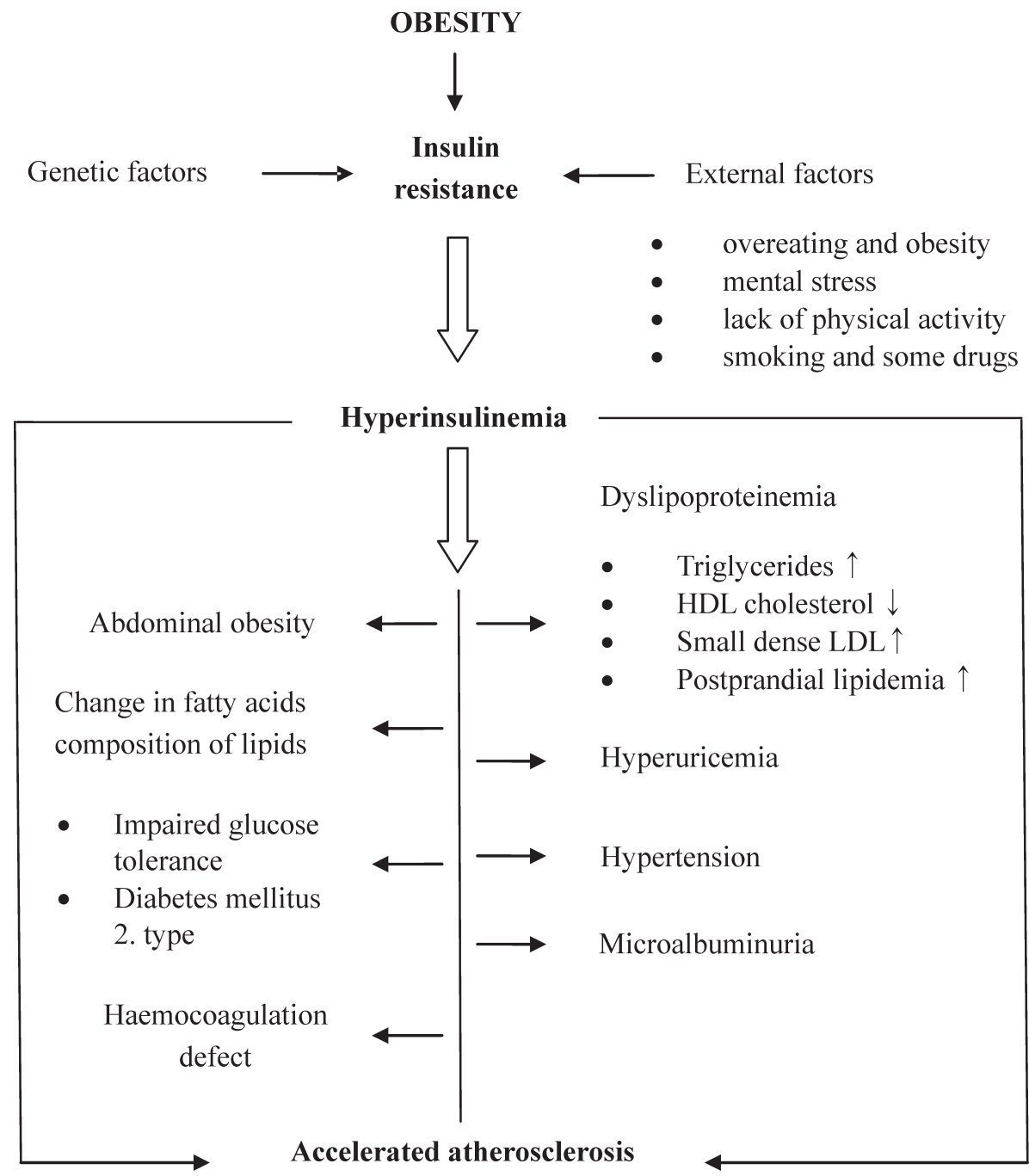

Fig. 1. A summary of IR causes and their metabolic consequences (Klimeš 1998). 
Tab. 1. Diagnostic criteria of MS according to WHO, NCEP-ATP III, EGIR and IDF (Akitunde and Akinwusi 2011, Ritchie and Conell 2007, Strazzulo at al.2008).

\begin{tabular}{|c|c|c|c|c|}
\hline & WHO$^{1}$ & NGEP-ATP-III $^{2}$ & EGIR $^{3}$ & IDF $^{4}$ \\
\hline Definition & $\begin{array}{l}\text { Diabetes or elevated } \\
\text { fasting blood glucose } \\
\text { or insulin resistance } \\
\text { in combination with } \\
2 \text { or more of follow- } \\
\text { ing criteria: }\end{array}$ & $\begin{array}{l}3 \text { or more from } \\
\text { following criteria: }\end{array}$ & $\begin{array}{l}\text { The present of } \\
\text { insulin resistance } \\
\text { and } 2 \text { or more from } \\
\text { following criteria: }\end{array}$ & $\begin{array}{l}\text { The abdominal obesity } \\
\text { (the criteria below are for } \\
\text { European population) }\end{array}$ \\
\hline $\begin{array}{l}\text { Obesity } \\
\text { woman } \\
\text { man }\end{array}$ & $\begin{array}{l}\text { WHR } \\
\text { (waist-hip ratio) } \\
>0.85 \\
>0.90 \\
\mathrm{BMI}>30 \mathrm{~kg} / \mathrm{m}^{2}\end{array}$ & $\begin{array}{l}\text { Waist circumference } \\
>88 \mathrm{~cm} \\
>102 \mathrm{~cm}\end{array}$ & $\begin{array}{l}\text { Waist circumference } \\
>80 \mathrm{~cm} \\
>94 \mathrm{~cm}\end{array}$ & $\begin{array}{l}\text { Waist circumference } \\
>80 \mathrm{~cm} \\
>90 \mathrm{~cm}\end{array}$ \\
\hline Fasting glucose & & $6.1 \mathrm{mmol} / \mathrm{L}$ & $\geq 6.1 \mathrm{mmol} / \mathrm{L}$ & $\geq 5.6 \mathrm{mmol} / \mathrm{L}$ \\
\hline Microalbuminuria & $\begin{array}{l}\geq 20 \mathrm{mg} / \mathrm{min} \text { or ratio } \\
\text { albumin/creatinine } \\
30 \mathrm{mg} / \mathrm{g}\end{array}$ & & & \\
\hline Triglycerides & $\geq 2.5 \mathrm{mmol} / \mathrm{L}$ & $\geq 2.5 \mathrm{mmol} / \mathrm{L}$ & $\geq 2 \mathrm{mmol} / \mathrm{L}$ & $\geq 2.5 \mathrm{mmol} / \mathrm{L}$ \\
\hline $\begin{array}{l}\text { HDL-cholesterol } \\
\text { women } \\
\text { men }\end{array}$ & $\begin{array}{l}<1.3 \mathrm{mmol} / \mathrm{L} \\
<1.0 \mathrm{mmol} / \mathrm{L}\end{array}$ & $\begin{array}{l}<1.3 \mathrm{mmol} / \mathrm{L} \\
<1.0 \mathrm{mmol} / \mathrm{L}\end{array}$ & $<1.01 \mathrm{mmol} / \mathrm{L}$ & $\begin{array}{l}<1.3 \mathrm{mmol} / \mathrm{L} \\
<1.0 \mathrm{mmol} / \mathrm{L}\end{array}$ \\
\hline Blood pressure & $\geq 140 / 90 \mathrm{mmHg}$ & $\geq 135 / 85 \mathrm{mmHg}$ & $\geq 140 / 90 \mathrm{mmHg}$ & $\begin{array}{l}\geq 135 / 85 \mathrm{mmHg} \text { or } \\
\text { treatment of hypertension }\end{array}$ \\
\hline
\end{tabular}

${ }^{1}$ WHO - World Health Organisation.

${ }^{2}$ NCEP-ATP-III - National Cholesterol Education Program - NCEP, Adult Treatment Panel - ATP III.

${ }^{3}$ EGIR - European Group for the Study of Insulin Resistance.

${ }^{4} \mathrm{IDF}$ - International Diabetes Federation.

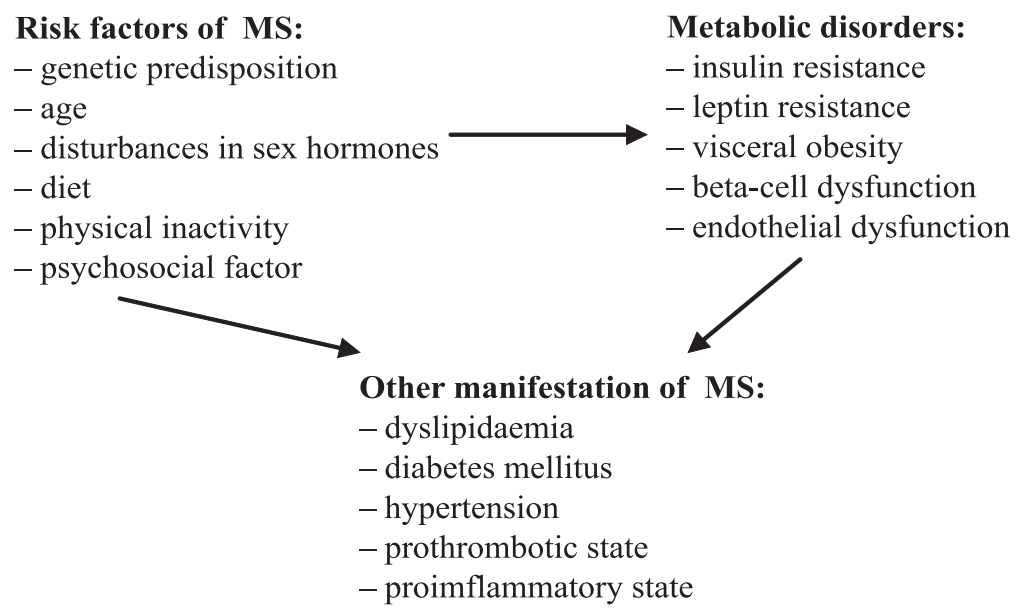

Fig. 2. A comprehensive framework for the etiology of MS (Fan 2007).

velopment are aging, race (Procopiou and Philippe 2005), menopause, sex hormone imbalance-as polycystic ovarian syndrome and hyperandrogenism in post-menopausal women (Korhonen at al. 2003), increased intake of carbohydrates, lipids, meat, low fibre intake, family anamnesis, lifestyle (smoking, alcohol drinking, mental inactivity), snoring, obstructive sleep apnoea syndrome, psychosocial and personality factors-belonging to lower social class and having problems to handle stressful situations (Caroll et al. 2000). Long-term interaction (Fig. 2) of these risk factors may lead to the development of metabolic disorder such as IR, dyslipidaemia, HT, protrombic and proinflammatory state and other conditions that will ultimately determine environmental and genetic bases for development and progression of MS (Fan 2007).

The synergistic effect of these factors leads to the excessive formation of adipose tissue and consequently to the development of obesity. The visceral adipose tissue secretes inflammatory cytokines and adipokines (leptin, resistin, interleukin-6 - IL-6, 
plasminogen-activator inhibitor-1 - PAI-1 and tumor-necrosis factor- $\alpha-\mathrm{TNF}-\alpha$ ) as well as nonesterified fatty acids (Fig. 3). These factors contribute to IR development at the level of skeletal muscle and liver with consequent hyperinsulinemia. IR contributes to endothelial dysfunction, dyslipidaemia and atherogenesis. The fatty acids also alter hepatic lipid production toward a pro-atherogenic profile (low levels of high-density lipoproteins, elevated amounts of low-density lipoproteins and TAG). Taken together, the increased amount of visceral adipose tissue is in the centre of the metabolic derangements that make up the MS (Bays 2009, Potenza and Mechanick 2009).

\section{Components of the metabolic syndrome}

Based on the information in the previous part of the review, for better understanding of MS it is important to describe its substance more deeply. This part of the article summarizes the latest available knowledge about obesity, type 2. diabetes, atherogenic dyslipidaemia, HT and inflammatory status, and their interconnection.

Obesity

Obesity is chronic disease characterized by an excess of body fat stores, which are caused by an imbalance between energy intake and energy expenditure (Vijver et al., 2009). Central obesity, associated with metabolic and cardiovascular diseases, is called visceral or android obesity according to recent IDF criteria (Krahulec at al. 2009). The degree of obesity can be measured using several parameters. One of them is Body mass index (BMI) calculated as ratio of weight in $\mathrm{kg}$ divided by the height in $\mathrm{m}^{2}$ (Svačina and Bretšnajdrová 2008). A more accurate indicator of the risk assessment is determining of body fat percentage $(\% \mathrm{BF})$. The gold standard for $\%$ BF measurement is considered dual energy X-ray absorptiometry (Gutin et al., 1996, Salamone et al. 2000), easier and non-invasive method is bioelectric impedance. This method is based on determining of the resistance of the body by which electric current of low intensity and high frequency passes (Heiner at al. 1997). The other reliable methods are the measurement of waist circumference and waist hip ratio (WHR) (Eaton-Evans 2005, Rytting 2005).

Fat cells, called adipocytes, actively secrete a variety of products that create a link among obesity and other components of MS. These biologically important substances called adipocytokines (leptin, resistin, adiponectin, free fatty acids, TNF- $\alpha$, IL-6, PAI-1, angiotensinogen, resistin, vistafin and glucocortikoids) (Formiguera and Canton 2004, Monteiro and Azevedo 2010). Elevated serum levels of proinflammatory adipocytokines IL- 6 and TNF- $\alpha$ have been observed in obese patients (Diamant et al. 2005). According to Rask-Madsen et al. (2003), TNF- $\alpha$ induces IR by reducing insulin receptor kinase activity. TNF- $\alpha$ also inhibits endothelial vasodilation and consequently induces endothelial dysfunction. Elevated levels of IL-6 correlated with

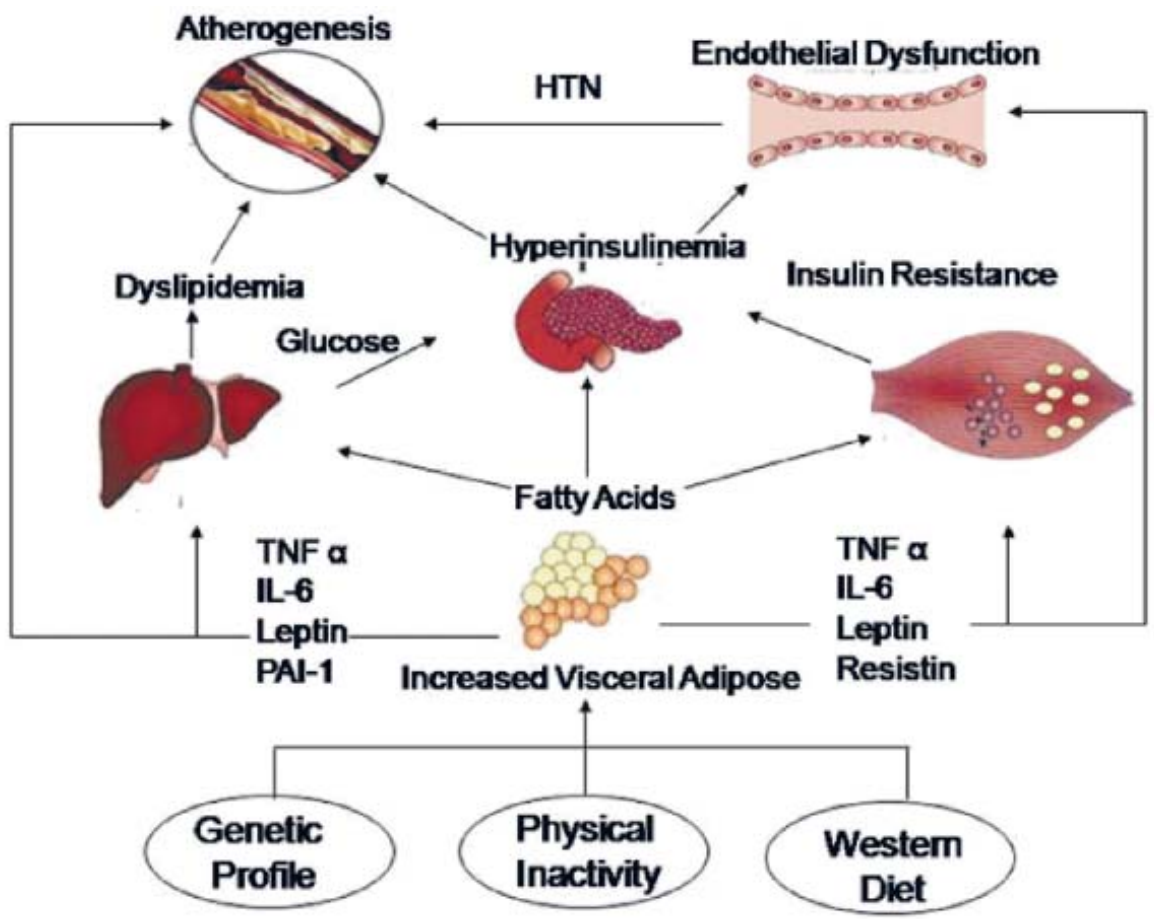

Fig. 3. Pathophysiology of MS (Potenza and Mechanick 2009). HTN - hypertension, TNF- $\alpha-$ tumor necrosis factor $\alpha$, IL-6 - interleukin 6 , PAI-1 - plasminogen activator inhibitor. 
insulin resistance markers (Bastard et al.2002). It is confirmed the impact of resistin on the development of IR and glucose intolerance in rodents. Despite of those facts the knowledge of the resistin effects on insulin and glucose tolerance in humans confirmed yet (Lam et al. 2000). The link of adiponectin with obesity and MS is more pronounced than in the previous hormones. Adiponectin is involved in increasing insulin sensitivity, reducing atherosclerosis, promoting of fatty acids oxidation, decreasing of fatty acids synthesis and stimulating in endothelial nitric oxide production through phosphorylationnitric oxide synthase gene (Ritchie and Conel 2007, Rabe et al. 2008). Hypoadiponectinemia occurs in people with obesity, diabetes, HT, hypertriglyceridemia, low HDL-cholesterol levels and predicts cardiovascular events (Ryo et al., 2004).

\section{Insulin resistance and type 2. diabetes}

The free fatty acids (FFAs) play an important role in the development of IR. Circulating FFAs are primarily derived from the cleavage of TAG of fat deposits by enzymes, notably fatty triacylglycerol lipase and hormone sensitive lipase (Petersen and Shulman 2006). FFAs released from intra-abdominal adipose tissue enter into circulation and these are involved in various organs (liver, muscles, etc.) of developing symptoms of IR. The excess of FFAs in the liver leads to stimulation of gluconeogenesis and hepatic glucose output, which contribute to the development of increased fasting plasma glucose, and the type 2. diabetes. In liver develops steatosis which leads to increased TAG and VLDL production and secretion with the subsequent development of atherogenic dyslipidemia (Grundy et al. 2005, Donohoe et al. 2011).

The high amount of FFAs inhibits the function of glucose transporter GLUT4 in the skeletal muscles. The skeletal muscle is the most important tissue of the total glucose utilization in the body, up to $75 \%$ of glucose is utilized here (Kelley et al. 1992). The inhibition of glucose transporter GLUT4 causes reduction in glucose uptake in muscle what is manifested in a postprandial hyperglycemia. Similarly to liver, it leads to the development of intramyocelular fat accumulation and impairment of mitochondrial function. There is an assumption that the increased influx of FFAs into pancreatic $\beta$-cell through lipotoxicity mechanism contributes to the loss of their secretory capacity and definite manifestation of type 2. diabetes (Tkáč 2006).

IR and impaired insulin secretion play a major role in the pathogenesis of development of type 2. diabetes. Further abnormalities associated with diabetes mellitus of this type are: increased hepatic glucose production, impaired insulin secretion in pancreatic $\beta$-cells (Fig. 4.) (Abate 2000, Pérez and Gómez 2011).

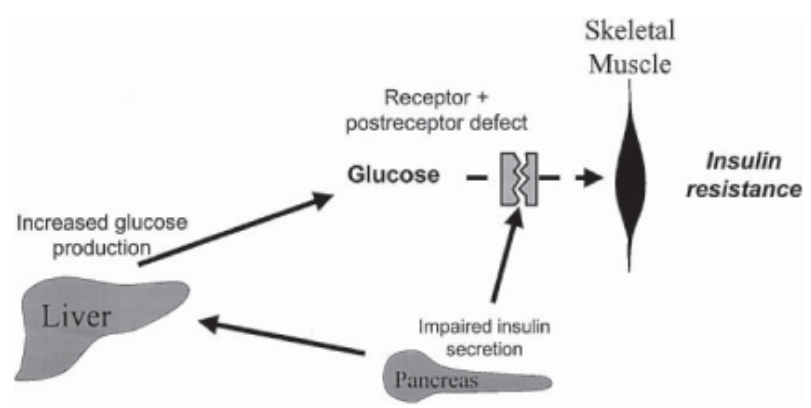

Fig. 4. The pathogenesis of type 2. diabetes associated with obesity (Abate 2000).

The presence of fasting hyperinsulinemia is characteristic in patients with mild form of type 2. diabetes. The insulin controls the stimulated secretion and it is passed during the food intake and is crucial in the regulation of postprandial glycaemia (Hideki et al. 1982, Donora et al. 2008).

Permanent tendency to fasting hyperglycaemia increases basal insulin secretion, with consequent depletion of the insulin in $\beta$-cells, which absent postprandially. Secretory capacity of $\beta$-cells decreases as a result of long-acting toxic effect of hyperglycaemia (glucotoxicity) and dyslipidemia (lipotoxicity) (Klimeš 1998).

\section{Atherogenic dyslipidemia}

Atherogenic dyslipidemia occurs commonly in obese individuals. This condition is characterized by increased concentration of TAG in the blood (also an increased number of VLDL particles), levels of LDL and apolipoprotein B (apoB) particles and low HDL cholesterol (Tan 2007, Kumar and Singh 2010).

LDL particles are closely associated with MS and are low-density lipoproteins. Small LDL particles are more atherogenic than larger LDL (Krauss, 1995) because they have the ability to easily pass through the vessel wall, where LDL is more susceptible to atherogenic changes. A higher amount of small LDL particles is associated with increased atherogenic potential (Blake at al. 2002).

A simple way to calculate the total number of atherogenic particles (atherogenic index) is determination LDL plus VLDL cholesterol or total apoB (NCEP 2002). LDL plus VLDL cholesterol and total apoB is usually increased in the subjects with MS and atherogenic dyslipidemia. The relevant determination should be used more widely in assessing the risk of MS (Grundy 2002, Fábryová 2007).

Another characteristic of atherogenic dyslipidemia is lower HDL value (NCEP 2002). HDL is antiatherogenic particle, increasing reverse cholesterol 
transport, has anti-inflammatory properties and the ability to protect against the modifications of LDL (Scott 2004). Low levels of HDL strongly predict the development of atherosclerotic CVD (NGEP 2002).

\section{Arterial hypertension}

$\mathrm{HT}$, as a part of MS, is one of the most important risk factors for atherosclerosis. Pathogenesis of HT in obesity is not fully elucidated yet. Hormones, secreted by the adipose tissue (ghrelin, resistin, leptin, angiotensinogen), might contribute to the development of HT. The increased activity of the sympathetic and renin-angiotensin system also plays an important role. Leptin raises the sympathetic activity and the angiotensinogen, produced by hormonally active fat tissue, what is involved in the pathogenesis of HT in obesity. Further adipose tissue hormones (TNF- $\alpha$, resistin) are included in IR and they may indirectly increase blood pressure through endothelial dysfunction and impaired vasodilation (Majerčák 2006, Benmohammed et al. 2011).

IR contributes to HT by increased sensitivity to sodium intake, increased sodium and water retention in the kidneys, increased activity of $\mathrm{Na}^{+} / \mathrm{H}^{+}$ pump and decreased activity of $\mathrm{Na}^{+} / \mathrm{K}^{+}$pump, increased accumulation of intracellular $\mathrm{Ca}^{2+}$, sympathetic stimulation and decrease the synthesis of vasodilatory prostaglandins. Attention is drawn particularly to the increased sympathetic activity, which affects the circulation (increased heart rate, increased minute output and peripheral vasoconstriction) of the kidney and the endocrinemetabolic consequences (Majerčák 2006). The elevated systolic blood pressure in patients with MS is considered values $130-139$ and or diastolic blood pressure more than 85-89 mmHg (Sninčák 2006).

\section{Phytochemicals}

Phytochemicals are bioactive compounds contained in the plants that have no energy value. These compounds are usually produced in the plants to protect them against pests, diseases, to control the growth, or as pigments, essences and aromas (PerezVizcaino et al. 2006). Currently, it is known a huge amount of phytochemicals which mainly consists of flavonoids, glucosinolates (isothiocyanates and indoles), phenolic acids, phytates, phytoestrogens (isoflavones and lignans), fats and oils contained in vegetables, fruits, cereals, legumes and other plant sources (Surh 2002). They are characterized by various biological effects including antiobesity, cholesterol - lowering and antidiabetic properties (Surh et al. 2001).

\section{Polyphenolic compounds}

Polyphenols of plant origin are compounds that occur mostly as monomers carrying carbohydrate moieties (as simple sugars, disaccharides or oligosaccharides). Polyphenols in plants usually occur glycosylated mainly with glucose or rhamnose, but they can also be linked with galactose, arabinose, xylose and glucuronic acid (Lacueva et al. 2011). Phenolic compounds are often present in the form of phenolic acids and flavonoids (Liu 2007). In the next section, attention will be given to three main groups of phytochemicals (polyphenolic compounds, vitamins and omega fatty acids) that are important in terms of MS prevention.

They are mainly found in cereals, legumes, the fruit (strawberries, apples, and grapefruit), red wine and chocolate. They generally inhibit in vitro oxidation of low density lipoprotein particles and thus protect the body against atherogenesis, main factor of CVD (Moure and Cruz 2001; Basu 2010). This process is basically inflammatory and is induced by inflammatory cytokines TNF- $\alpha$ and IL-6. The chronic phase of CVD (formation of atherogenic plaques) may result in acute phase, thus thrombotic activity (formation of blood clots) in places of vascular damage. CVD is an example of unwanted inflammation in the body. Polyphenolic compounds are effective in regulating undesirable inflammatory aspects of CVD. Some low molecular proantocyanidins have the ability to inhibit the activity of specific enzymes as angiotensin-converting enzyme. According to Stevenson and Hurst (2007), the increased quercetin supplementation in animal experiments caused a reduction in blood pressure, normalization of the concentration of glutathione, glutathione peroxidase and nitric oxide (Stevenson and Hurst 2007). They also have a positive impact on the integrity of cell membranes of erythrocytes, thus normal blood fluidity and reduce the risk of stroke (Awika and Rooney 2004).

\section{Flavonoids}

The flavonoid basic structure consists of diphenylpropan (C6-C3-C6). Different number and position of substituents divide the flavonoids into classes (flavonols, flavones, flavans, or flavanols, catechins, isoflavones, flavanonols and anthocyanidins) (Prasain at al. 2010).

These phytochemicals exhibit many significant biological effects described in the polyphenolic section. Many clinical studies suggested the positive effects of flavonoids in preventing, treating and alleviating diseases including MS and its tripartite major contributors, i.e. diabetes, obesity and HT. They have a preventive effect against atherosclero- 
Tab. 2. Overview of major flavonoids possibly active in the prevention and treatment of MS (Teasun and Yunjung 2011).

\begin{tabular}{|c|c|c|c|}
\hline Flavonoid & Possitive effect & Flavonoid & Possitive effect \\
\hline Quercetin & $\begin{array}{l}\text { Blood pressure } \downarrow \\
\text { Visceral fat } \downarrow \\
\text { Lipid peroxidation } \downarrow \\
\text { Body fat accumulation } \downarrow \\
\text { Apoptosis of adipocytes } \uparrow\end{array}$ & Naringenin & $\begin{array}{l}\text { Blood lipids } \downarrow \\
\text { Fat accumulation } \downarrow \\
\text { Secretion of lipids } \downarrow\end{array}$ \\
\hline Genistein & $\begin{array}{l}\text { BMI } \downarrow \\
\text { Blood HDL } \uparrow \\
\text { Body fat mass } \downarrow \\
\text { Lipogenesis } \downarrow \\
\text { Blood glucose } \downarrow \\
\text { Glucose tolerance } \uparrow\end{array}$ & Kaempferol & $\begin{array}{l}\text { Blood lipids } \downarrow \\
\text { Body weight } \downarrow \\
\text { TAG } \downarrow\end{array}$ \\
\hline Daidzein & $\begin{array}{l}\text { Blood glucose } \downarrow \\
\text { Blood insulin } \uparrow \\
\text { Blood lipids } \downarrow \\
\text { Lipolysis } \uparrow\end{array}$ & Myricetin & $\begin{array}{l}\text { Blood glucose } \downarrow \\
\text { Insulin resistance } \downarrow \\
\text { TAG } \downarrow\end{array}$ \\
\hline (1) & $\begin{array}{l}\text { Blood lipids } \downarrow \\
\text { Blood glucose } \downarrow \\
\text { Fat accumulation } \downarrow \\
\mathrm{OH}\end{array}$ & Hesperetin & $\begin{array}{l}\text { Blood lipids } \downarrow \\
\text { Atherogenic index } \downarrow \\
\text { Fatty liver improved } \\
\mathrm{H}_{3}\end{array}$ \\
\hline HO & $\begin{array}{l}\text { Blood lipids } \downarrow \\
\text { Body weight } \downarrow \\
\text { Fatty liver } \downarrow \\
\text { Visceral fat } \downarrow\end{array}$ & $\mathrm{H}_{3} \mathrm{CO}$ & $\begin{array}{l}\text { Blood lipids } \\
\text { (cholesterol) } \downarrow \\
\mathrm{OH}\end{array}$ \\
\hline
\end{tabular}

sis, cancer, arthritis and may slow the aging process (Prasain at al. 2010).

Many epidemiological studies highlight the potential effects of catechins in preventing of MS. (Thielecke and Boschmann 2009). Data from in vitro and in vivo studies suggest that catechins increases fat oxidation. It leads to the reduction of body fat, weight loss, reduction serum TAG in hyperlipidemia, free fatty acids and total cholesterol. According to Thielecke and Boschmann (2009), catechins promote cardiovascular health. Other effects include for example, improving endothelial 
function, increasing antioxidant activity and better control of blood pressure.

Theaflavins (theaflavinn, teaflavin-3-gallate) are natural dyes occurring mainly in black tea. They have antioxidant and anticarcinogenic effects and counteract CVD, HT and obesity (Subramanian et al. 1999). Authors Ikeda et al. (2003) mentioned in their article that theaflavins are involved in reducing LDL cholesterol, thus decreasing the absorption of cholesterol from the intestine by inhibition of pancreatic lipase activity. These substances also showed a strong hypoglycemic effect by inactivation of alphaglukocosidase. They have ability to reduce concentrations of plasma lipids, increase energy expenditure in living organisms, thus a reduction of body weight and prevents obesity (Matsui et al. 2007).

Cyanidins are the most prevalent anthocyanin compounds in the plant kingdom. In addition to the antioxidant properties they have also neuroprotective, antidiabetic, gastroprotective and antiobesity properties (Galvano at al. 2007). Cyanidin-3-glucoside, called curomanin, is the most effective in the prevention of diabetes and obesity. It occurs mainly in the maize. Tsuda et al. (2006) revealed that these substances significantly suppress weight gain, adipose tissue, hyperglycemia and hyperinsulinemia by inhibition of enzymes involved in the synthesis of fatty acids and TAG.

Isoflavones (genistein, diadzein, glycitein) are found mainly in soybeans and soya products. The chemical structure of isoflavones is very similar to the human estrogen. Due to this similarity isoflavones can influence the activity of human estrogen. Therefore, increased consumption of soy products may be associated with protective effects against breast, prostate cancer, heart disease and osteoporosis. Isoflavones have a positive impact on glucose homeostasis, insulin secretion and lipid metabolism. They lower blood cholesterol and TAG levels (Cederoth 2009, Teasun and Yunjung 2011).

Quercetin has a wide range of biological effects. One of the most important is the potency to reduce blood pressure. Quercetin has also potential antiobesity effects through inhibition of preadipocytes differentiation and induction of apoptosis of mature adipocytes (Teasun and Yunjung 2011, Bischhof 2008).<smiles>COc1cc(CNC(=O)CCCC/C=C/C(C)C)ccc1O</smiles>

Rutin is an important component of beverages made from plant material. It exhibits pharmacological activity including antioxidant, anticarcinogenic, neuroprotective, antithrombotic and cardioprotective effects. It can reduce the blood levels of insulin and leptin (Tesun and Yunyung 2011). Some studies have demonstrated the ability of rutin to inhibit glycerol-3-phosphate dehydrogenase, an enzyme in the cytosol, which is important in converting glycerol to triacylglycerol in preadipocyte in adipose tissue and liver (Kuntic et al. 2007, Hsu et al. 2009).

The Table 2. summarizes positive effects of above mentioned and other flavonoids in the prevention and treatment of MS.

Phenolic acids

Phenolic acids are aromatic secondary plant metabolites. The most represented phenolic acids in plants are hydroxybenzoic and hydroxycinnamic acids. Phenolic acids exhibit anti-inflammatory, antimutagenic and anticarcinogenic properties. Besides these properties, their antiobesity effects attributed to the gallic acid, capsaicin, curcumin and coumaric acid were shown (Stalikas 2007, Hsu 2008). The basic chemical structure and classification of the phenolic acids is presented in the Table 3 .

Tab. 3. Chemical structure and classification of phenolic acids (Naczk and Shadiky 2004).

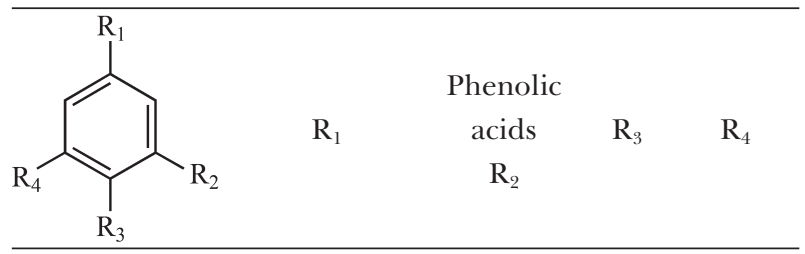

\begin{tabular}{lllll}
\hline Protocatechic & $\mathrm{COOH}$ & $\mathrm{OH}$ & $\mathrm{OH}$ & $\mathrm{H}$ \\
\hline Vanillic & $\mathrm{COOH}$ & $\mathrm{OCH}_{3}$ & $\mathrm{OH}$ & $\mathrm{H}$ \\
\hline Syringic & $\mathrm{COOH}$ & $\mathrm{OCH}_{3}$ & $\mathrm{OH}$ & $\mathrm{OCH}_{3}$ \\
\hline Gallic & $\mathrm{COOH}$ & $\mathrm{OH}$ & $\mathrm{OH}$ & $\mathrm{OH}$ \\
\hline P-Coumaric & $(\mathrm{CH})_{2} \mathrm{CO}_{2} \mathrm{H}$ & $\mathrm{H}$ & $\mathrm{OH}$ & $\mathrm{H}$ \\
\hline Caffeic & $(\mathrm{CH})_{2} \mathrm{CO}_{2} \mathrm{H}$ & $\mathrm{OH}$ & $\mathrm{OH}$ & $\mathrm{H}$ \\
\hline Ferulic & $(\mathrm{CH})_{2} \mathrm{CO}_{2} \mathrm{H}$ & $\mathrm{OCH}_{3}$ & $\mathrm{OH}$ & $\mathrm{H}$ \\
\hline Cinnamic & $(\mathrm{CH})_{2} \mathrm{CO}_{2} \mathrm{H}$ & $\mathrm{OCH}_{3}$ & $\mathrm{OH}$ & $\mathrm{OCH}_{3}$ \\
\hline & & & &
\end{tabular}<smiles>COc1cc(/C=C/C(=O)CC(=O)/C=C/c2ccc(O)c(OC)c2)ccc1O</smiles>

Fig. 5. The chemical structure of capsaicin (A) and curcumin (B). 
It was described the ability of gallic acid to reduce preadipocytes proliferation by induction of cell apoptosis. The gallic acid shows antiobesity, hypolipidemic properties and the ability to reduce oxidative stress in animal models (Hsu et al. 2006, Theasun and Yunjung 2011).

Capsaicin (Fig. 5) is the most pungent component of red pepper used as seasoning. Capsaicin can reduce the energy intake, weight gain and decrease serum TAG. It also induces apoptosis of adipocytes, thereby violating the mitochondrial membrane potential. Capsaicin has the ability to reduce the levels of inflammatory cytokines TNF- $\alpha$ a and IL-6 (Macho et al. 2003, Hwang et al. 2005).

Curcumin is a yellow pigment, which is obtained from dried plant rhizomes Curcuma longa. It is a popular spice used in curry in Asia. Curcumin acts as an antioxidant, anticarcinogenic and antiinflammatory agent. Lao et al. (2006) mentioned in their study antiobese, antidiabetic and cholesterollowering effects of curcumin.

Coumaric acid is hydroxyl-derivate of the cinnamic acid. The most represented coumaric acid isomer in the nature is $p$-coumaric acid. It is known as an antioxidant and anti-inflammatory agent. Coumaric acid can reduce weight, increasing in adipose tissue, as well as serum cholesterol, TAG, insulin and leptin and the risk of liver steatosis in rats (Lucery et al. 2004, Hsu et al. 2009).

\section{Vitamins}

Patients affected by MS have insufficient endogenous and exogenous antioxidant defences and therefore they are under the influence of oxidative stress. Oxidative stress can be defined as an imbalance between reactive oxygen species and antioxidant protection. Oxidative stress plays an important role in the pathophysiology of CVD and diabetes. Oxidation of LDL particles may be a key step in atherogenesis (Horn et al. 2008).

Increased lipid peroxidation and serum levels of malondialdehyd, reduced activity of superoxiddismutase in erythrocytes and decreased plasma levels of glutathionperoxidase, vitamin C, D and $\mathrm{E}$, nitric oxide and polyunsaturated fatty acids in membranes of erythrocytes, reduced glutathione and increased production of hydrogen peroxide in the plasma was observed in patients with MS (Wen et al. 1996, Russo et al. 1998).

It is described an indirect correlation among increased production of free radicals and insulin action in the scientific studies. Most of these studies point to an indirect association between IR, and concentration of antioxidants, and the improving the effectiveness of insulin by providing more antioxidants (Ford et al. 2003).
In connection with the foregoing, the vitamins-especially vitamin $\mathrm{D}$, and antioxidative active vitamin $\mathrm{C}$ and $\mathrm{E}$ are substantially important in preventing of MS, which except of antioxidant properties have also other positive effects. Its low intake may adversely affect the cardiovascular system. Its low concentrations in serum are associated with the development of HT, obesity, IR and hence MS (Draznin et al. 1987).

Vitamin D acts as an endocrine regulator of the renin-angiotensin system (Shilpa et al. 2011). It also plays an important role in the metabolism of insulin. Its serum levels are indirectly correlated with insulin sensitivity, fasting insulin levels and the activity of lipoproteinlipase in adipose tissue and skeletal muscle (Tai et al. 2009). It can reduce IR and increased insulin secretion in type 2. diabetes by creating a balance between the intracellular and extracellular calcium in $\beta$-cells. Scientific studies have shown a significant relationship between levels of vitamin D3 and reducing the blood pressure in hypertensive patients. This vitamin also has indirect effect on $\mathrm{Ca}^{2+}$ transport and its metabolism and excretion. Just low concentrations of $\mathrm{Ca}^{2+}$ were observed in the serum of hypertensive patients with low renin levels (Dakshinamurti and Lal 1996, McCarron 1986, Houston 2005).

Vitamin C is a water soluble vitamin and a very effective antioxidant. It is the quencher of free radicals, thus acts as an important factor in preventing of CVD. It is also active in LDL lowering and total cholesterol and TAG levels in the blood (Shilpa et al. 2011). Numerous clinical studies have shown that increased intake of vitamin $\mathrm{C}$ in the diet has beneficial properties on endothelial dysfunction. Concentrations of vitamin $\mathrm{C}$ and ascorbate levels are in indirect correlation with systolic and diastolic blood pressure, and also HT. Increased intake of antioxidant-acting vitamin reduces the risk of CVD (Salonen et al. 1988, Ceriello et al. 1991). It restores nitric oxide-mediated vasodilatation. The effect of vitamin $\mathrm{C}$ leads to an increase in exhaled nitric oxide, which is associated with a reduction in blood pressure. Combining vitamin $\mathrm{C}$ with vitamin $\mathrm{E}, \beta$-carotene and selenium also has significant synergistic antihypertensive effect. Other antihypertensive mechanism of vitamin $\mathrm{C}$ include the ability to reduce the production of adrenaline steroids, cytosolic $\mathrm{Ca}^{2+}$ concentration, to recycle vitamin $\mathrm{E}$, glutathione and uric acid, to reduce the neuroendocrine peptides and thrombosis, to improve elasticity of blood vessels and to activate sodium channels of smooth muscle of blood vessels (Houston 2005, Bates et al. 1998).

Vitamin E is a fat soluble vitamin and antioxidant. There are four forms, namely alpha-, beta-, gamma- 
and delta-isomers. Its main role is to protect biological membranes against the effects of free radicals (Shilpa et al. 2011). Vitamin E preventively acts against cardiovascular disease by preventing of LDL oxidation. Oxidative LDL is a potent chemokine that induces adhesion and influx of monocytes, which subsequently causes the release of cytokines. Proinflammatory cytokines such as TNF- $\alpha$, IL-6 cause the retaining of monocytes to endothelium (Devaraj et al. 2008). $\alpha$-Tocopherol is involved in reducing the secretion of thrombin in the endothelium, which contributes to the improvement of endothelial dysfunction and reduction in blood pressure. $\gamma$-Tocopherol contributes to a significant reduction of lipid peroxides in plasma and the walls of blood vessels, increasing the activity of superoxide dismutase and total antioxidant status and reduction in blood pressure. The literature describes synergistic effect of combinations of $\alpha$-tocopherol and tocotrienols (Newaz and Nawal, 1999, Koba et al. 1992).

Results from clinical studies demonstrate the positive effect of vitamin E on IR, lowering blood glucose and increasing concentrations of glutathione levels. Vitamin E contributes to the reduction of endothelial dysfunction. The significantly lower levels of vitamin $\mathrm{E}$ and $\mathrm{C}$ were reported in plasma and also in cells in hypertensive patients compared with healthy subjects (Houston 2005).

\section{Omega-fatty acids}

Omega-3-fatty acids

They are essential fatty acids. Important $\omega$-3-fatty acids in dietary terms include $\alpha$-linolenic acid ( $\alpha$ ALA), eicosapentaenoic acid (EPA) and docosahexaenoic acid (DHA) (VanHorn et al. 2008, Houston 2005). Their chemical structure is summarized in the table 4 .

Tab. 4. The chemical structure of $\omega$-3-fatty acids (Blondeau and Schneider 2006).

Omega-3-fatty acid

They are characterized by several positive effects in treating MS. They can reduce blood pressure, reduce plasma levels of TAG, and increase HDLcholesterol. $\omega$-3-fatty acids are the reduction factor of proinflammatory state and have a positive effect on IR (Couet et al. 1997, Mori et al., 2004). Therefore, just eating fish containing $\omega$ - 3 -fatty acids is an important part of diet in patients with MS. $\omega$-3-fatty acids can slow down the synthesis of inflammatory cytokines TNf- $\alpha$ and IL-1, inhibit the adhesion of molecules on endothelium and thus contribute significantly to reducing of risk of CVD (Brown and $\mathrm{Hu}$ 2001). $\omega$-3-fatty acids have positive cerebrovascular events. They reduce levels of fibrinogen, exhibit anti-inflammatory, antiplatelet, lipid-lowering, anti-arrhythmic and vasodilator effects (increased levels of nitric oxide), affect the permeability of cell membranes (De Busk 2000). They decrease IR through several mechanisms. Increased inflammatory process is one of the main factors leading to the development of IR. EPA can reduce the production of inflammatory eicosanoids from arachidonic acid by entering the competition with enzymes like cyklooxygenase and lipooxygenase. EPA together with DHA reduces the release of arachidonic acid by inhibiting of phospholipase-2 (Fedor and Kelley 2009). Many of adipocytokines (leptin, adiponectin, resistin and vistafin), released from adipose tissue, contribute to the development of IR. Many studies showed that $\omega$-3-fatty acids regulate the secretion of these hormones (Houston 2005). $\omega$-3-fatty acids regulate the expression of many genes involved in lipid and carbohydrate metabolism by influencing the activity of transcription factors (Fedor and Kelley 2009). These acids also positively influence to the metabolism of lipids and lipoproteins in patients with MS (Fig. 6). These effects are attributed to EPA and DHA and their combinations. EPA is involved in the reduction of serum TAG. Reduced production of VLDL in the liver is the result of decreased availability of free fatty acids from adipose tissue, suppression of lipogenetic genes and induction of genes involved in fatty acid oxidation. They also reduce the production of apoB. Increased lipolytic activity of lipoproteinlipase in extrahepatic tissues completes hypolipidemic effect of $\omega$-3-fatty acid. Although $\omega$-3-acids tend to slightly increase the concentration of LDL, this potential cardiovascular factor is compensated by reduction the number of atherogenic small dense lipoprotein particles. Studies in obese individuals showed the impact of $\omega$-3-fatty acids in reducing the plasma concentration of apoB and VLDL (Carpentier et al. 2006).

\section{Omega-6-fatty acids}

They include linoleic acid (LA), gamalinolenic acid (GLA), dihomo-gamma-linolenic acid (DGLA) and arachidonic acid (AA) (Table 5). 


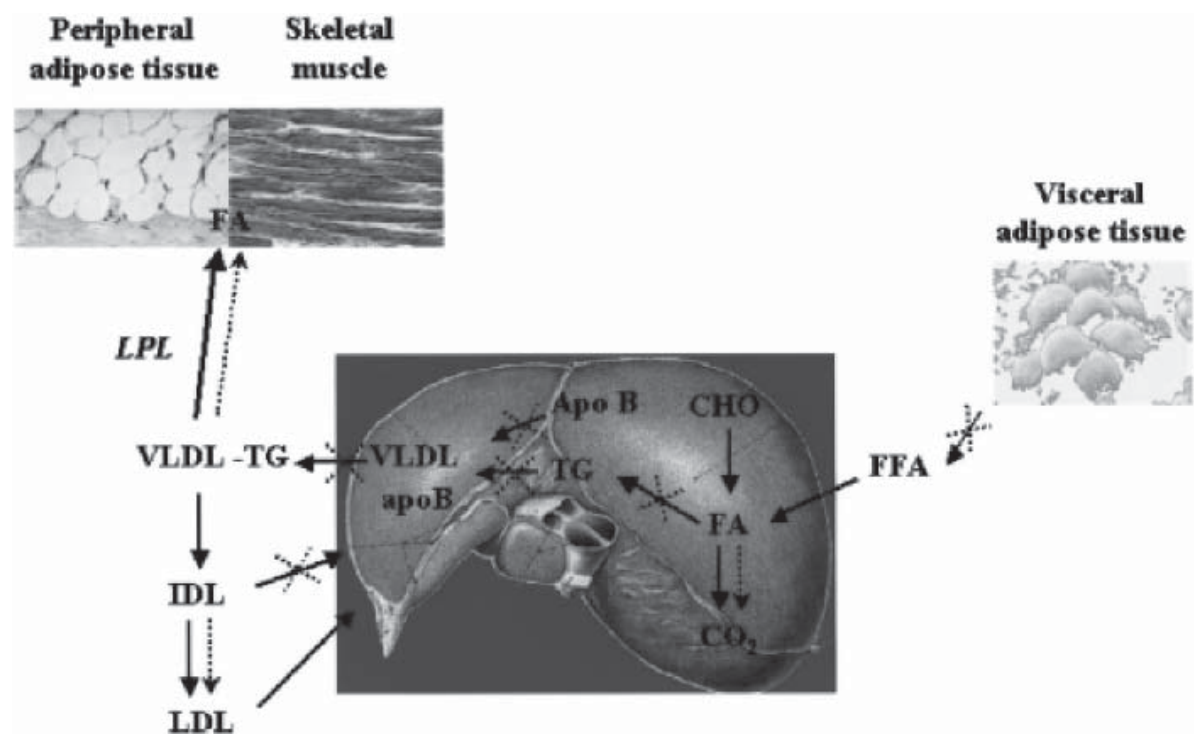

Fig. 6. Effect of $\omega$-3-fatty acids on lipid and lipoprotein metabolism in patients with MS (Carpentier et al. 2006). Apo - apolipoprotein, CHO - carbohydrate, FA - fatty acid, FFA - free fatty acid, LPL - lipotrotein lipase, IDL - intermediate-density lipoprotein, TG - triacylglycerol.

Tab. 5. The chemical structure of $\omega$-6-fatty acids (Blondeau and Schneider 2006).

Omega 3-fatty
acid

These acids do not always cause a significant reduction in blood pressure, but can prevent the increase in blood pressure induced by saturated fats (Morris 1994). The ideal ratio of $\omega-3$ and $\omega-6$ fatty acids is between $1: 1$ to $1: 2$ with a ratio of polyunsaturated to saturated fat 1:5 to 2:0 (Eaton and Konner 1997).

GLA and DGLA contribute to increasing the synthesis of vasodilatatory prostaglandins PG1 and PG2. These prostaglandins act against increasing of blood pressure. GLA also blocks stress-induced HT by reducing plasma aldosterone levels, and by reducing the density and affinity of adrenaline receptors. PG1 and PG2 regulate the transmission of nerve impulses, mental function, neurotransmitter release and functions which normalize the changes caused by stress in the hypothalamus and endocrine organs of hypertensive patients who consume increasingly GLA (Houston 2005).

\section{Conclusions}

MS is a complex of symptoms related to obesity, type 2. diabetes and HT. A significant increase has been observed in the incidence of these conditions over the last two decades, and both the scientific literature and the popular press now discuss the "epidemic" of both obesity and type 2. diabetes. MS is associated with increased risk of several chronic diseases including heart disease, stroke, and cancer.

There is strong evidence that diet, in conjunction with sedentary lifestyle and other risk factors, plays a role in the development of MS. Conversely, there is increasing epidemiological and laboratory evidence that certain classes of dietary phytochemicals may have preventive or therapeutic effects against one or more symptoms of MS.

The scientific literature and epidemiological data tend to show a positive association between especially polyphenols, predominantly flavonoids and phenolic acids, atioxidant vitamins such as vitamin C, D and E, $\omega-3$ and $\omega$-6-fatty acids and some minerals such as chromium and magnesium. These entire compounds may have positive effects on CVD, including improvements in endothelial function and lipoprotein profiles. The positive effect on the endothelial function could also be linked to the improvement observed in blood pressure and 
reduced risk of HT. Epidemiological studies tend to show a positive effect of mentioned phytochemicals on the prevention of diabetes. This effect should be induced by a reduced IR and an improvement in insulin sensitivity. These compounds have also been shown to exert antioxidant and anti-inflammatory actions; they interfere with signal transduction (direct inhibition of proinflammatory enzymes).

It is clear that the biological functions of mentioned phytochemicals in humans could play a role for health protection. But there are still areas to explore to better understand the potential of phytochemicals and to find other new compounds in preventing the lifestyle diseases.

\section{Acknowledgement}

This work was supported by The Agency of the Ministry of Education, Science, Research and Sport of the Slovak Republic for the Structural Funds of EU, OP RED of ERDF in the Frame of the Project "Evaluation of natural substances and their selection for prevention and treatment of lifestyle diseases" (ITMS 26240220040).

\section{References}

Abate N (2000) Journal of Diabetes and Its Complications 14: $154-174$.

Akitunde AA, Akinwusi PO (2011) Clinical Medicine\&Research, 9: 26-31.

Awika JM, Rooney LW (2004) Phytochemistry, 65: 1199-1221.

Balkau B, Valensi P, Eschwege E, Slama G (2007) Diabetes\&Metabolism 33: 405-413.

Bastard JP, Maachi M, Van Nhieu JT, Jardel C, Bruckert E, Grimaldi A, Robert JJ, Capeau J, Hainque B (2002) Journal of Clinica Endokrinology \& Metabolism 87: 2084-2089.

Basu A, Du M, Wilkinson M, Simmons B, Wu M, Betts NM, Fu DX, Lyons TJ (2010) Nutrition Research 30: 462-469

Bates CJ, Walmsley CM, Prentice A, Steven F (1998) Journal of Hypertensive 16: 925-932.

Bays HE (2009) American Journal of Medicine 122: 26-37.

Benmohammed K, Nguyen MT, Khensal S, Valensi P, Lezzar A (2011) Diabetes and Metabolism 37: 291-297.

Bischhof SC (2008) Current Opinion in Clinical Nutrition \& Metabolic Care 11: 733-40.

Blake GJ, Otvos JD, Rifai N, Ridker PM (2002) Circulation 106. 1930-1937.

Blondeau N, Schneider SM (2006) Nutrition clnique et metabolisme 20: 68-72.

Bray GA (2007) The Metabolic Syndrome and Obesity. Humana Press, New Jersey.

Brown AA, Hu FB (2001) American Journal of Clinical Nurition 73: 673-686.

Caroll S, Cooke CB, Buterly RJ (2000) Medicine \& Science in Sports \& Exercise 32: 2079-86.

Carpentier YA, Portois L, Malaisse WJ (2006) American Journal of Clinical Nutrition 83: 1499-504.
Cederroth CR, Nef (2009) Molecular and Cellular Endocrinology 304: 30-42.

Ceriello A, Giugliano D, Quatro A (1991) Clinical Science 81: 739-742.

Couet C, Delarue J, Ritz P, Antoine JM, Lamisse F (1997) International Journal of Obesity and Related Metabolic Disorders 21: 637-643.

Dakshinamurti K, Lal KJ (1996) World Review of Nutrition Dietetics 69: 40-73.

De Busk RM (2000) Current Aterosclerosis Reports 2: 508-514.

Devaraj S, Leonard S, Traber MG, Jialal I (2008) Free Radical Biology and Medicine 44: 1203-1208.

Diamant M, Lamb HJ, Van de Ree MA, Endert EL, Groeneveld Y, Bots ML, Kostense PJ, Radder JK (2005) The Journal of Clinical Endocrinology \& Metabolism 90: 1495-501.

Donohoe CL, Doyle SL, Reynolds JV (2011) Diabetology and Metabolic syndrome 3: 1-13.

Donora E, Capaldo B, Perin PC, DelPrato S, De Matia G, Frittitta L, Frontoni S, Leonoetti f, Luzi L, Marchesini G, Marini MA, Natali A, Paolisso G (2008) Nutrition, Metabolism and Cardiovascular Diseases 18: 624-631.

Draznin B, Sussmann K, Kao M, Lewis D, Sherman N (1987) Journal of Biology and Chemistry 262. 14385-14388.

Eaton SB, Konner MJ (1997) European Journal of Clinical Nutrition 51: 207-216.

Eaton-Evans J (2005). In: Caballero B (Ed) Encyclopedia of Human Nutrition, Vol 4 (pp 311-318) Elsevier Academic Press, Oxford.

Fábryová L' (2007) Via Practika 4: 13-18.

Fan ZA (2007) Current Cardiology reviews 3: 232-239.

Feldeisen SE, Trucker KL (2007) Applied Physiology, Nutrition and Metabolism 32: 46-60.

Ford AS, Mokdad AH, Giles WH, Brown DW (2003) Diabetes 52: 2346-2352.

Formiguera X, Cantón A (2004) Best Practice and Research Clinical Gastroenterology 18: 1125-1146.

Galajda P, Mokáň M (2004) Diabetes a obezita 7: 39-49.

Galajda P, Mokáň M (2006) Diabetes a obezita 11: 73-79.

Galvano F, La Fauci L, Lazzarino G, Fogliano V, Ritieni A, Ciappellano S, Ciappelanno S, Battistini NC, Tavazzi B, Galvano G (2004) Journal of Nutrition Biochemistry 15: 2-11.

Grundy SM (2002) Circulation 106: 2526-2529.

Grundy SM, Cleeman JI, Daniels SR, Donato KA, Eckel RH, Franklin BA, Gordon DJ, Krauss RM, Savage PJ, Smith SC, Spertus JA, Costa F (2005) Circulation 112: 2735-2752.

Gutin B, Litaker M, Islam S, Manos T, Smith C, Treiber F (1996) American Journal of Clinical Nutrition 63: 287-292.

Hainer V, Kunešová M (1997) Obezita - Etiopatogeneze, diagnostika a terapie. Galén, Praha. Hideki H, Nagulesparan M, Klimeš I, Clark R, Sasaki H, Aronoff SL, Vasquez B, Rubenstein A, Unger RH (1982) Journal of Clinical Endocrinology and Metabolism 54: 217-222.

Horn L, McCoin M, Penny M, Burke F, Carson JS, Champagne CM, Karvally W, Sikand G (2008) Journal of the American Dietetic Association 108: 287-331.

Houston MC (2005) Nutraceuticals and Hypertension 47: 396-449. 
Hsu CL, Huang SL, Yeng C (2006) Journal of Agriculture and Food Chemistry 54: 4191-4197.

Hsu CL, Wu CH, Huang SL, Yen GC (2009) Jounal of Agriculture Food and Chemistry 57: 425-431.

Hsu CL, Yen GC (2008) Molecular Nutrition \& Food Research 52: 53-61.

Hvang JT, Park IJ, Shin JT, Lee YK, Lee SK, Baik HW, Ha J, Park OJ (2005) Biochemical and Biophysical Research Communications 338: 694-699.

Ikeda I, Kobayashi M, Hamada T (2003) Journal of Agriculture and Food Chemistry 51: 7303-7307.

Kelley DE, Makáň M, Mandarino LJ (1992) Diabetes 41: 698-706.

Kelley DS, Fedor D (2009) Current Opinion in Clinical Nutrition and Metabolic Care 12: 138-146.

Klimeš I (1998). In: Vozár J, Krese A, Klimeš I Diabetes mellitus, (pp70-77), Slovak Academic Press, Bratislava

Koba K, Abe K, Ikeda I, Sugano M (1992) Bioscience, Biotechnology and Biochemstry 56: 1420-1423.

Korhonen S, Hippelainen M, Vanhala M, Heinonen S, Niskanen L (2003) Fertility and Sterility 79: 1327-34.

Krahulec B (2008). In: Mokáň M a kol., (eds) Diabetes mellitus a vybrané metabolické ochorenia (pp 756767). P+M, Martin.

Krahulec B, Klimeš I, Fábryová L (2009) Algoritmy liečby 2: 3-13.

Krauss RM (1995) American Journal of Cardiology 75: 53-57.

Kumar A, Singh V (2010) Vascular Health and Risk Management 6: 665-669.

Kuntic V, Pejic N, Ivkovic B (2007) Journal of Pharmaceutical and Biomedical Analysis 43: 718-721.

Lacueva CA, Remon AM, Llorach R, Sarda UM, Khan N, Blanch GC, Ros ZR, Ribalta RM, Raventós RML (2011). In: Rosa LA, Parilla EA, Aguilar GAG Fruit and Vegetable Phytochemicals, Vol 1 (53-88). WileyBlackwel, USA.

Lam KSL, Xu A, Wat NMS., Tso AVK, Ip MSM (2000) International Congress Series 1262: 542-545.

Lao CD, Ruffin MT, Normolle D., Heath DD, Murray SI, Bailey JM, Boggs ME, Crowell J, Rock CL, Brenner DE (2006) BMC Complementary and Alternative Medicine 6: 10-20.

Liu RH (2007) Journal of Cereal Science 46: 207-219.

Luceri C, Guglielmi F, Lodovici L, Giannini L, Messerini L, Dolara P (2004) Scandinavian Journal of Gastroenterology 39: 1128-33.

Macho A, Sancho R, Minassi A, Appendino G, Lawen A, Muñoz E (2003) Free Radical Research 37: 611-609.

Majerčák I (2006) Via Practica 6: 298-300.

Matsui T, Tanaka T, Tamura S, Toshima A, Tamaya K, Miyata Y, Tanaka K, Matsumoto K (2007) Journal of Agriculture and Food Chemistry 55: 99-105.

McCarron DA (1989) Kidney International 35: 717-736.

Monteiro R, Azevedo I (2010) Mediators of Inflammation: $1-10$.

Mori TA, Burke V, Puddey IB, Shaw JE, Beilin LJ (2004) Journal of Hypertension 22: 983-990.

Moris MC (1994) Journal of Cardiovascular Risk 1: 21-30.

Moure A, Cruz JM, Franco D, Domínguez JM, Sineiro J, Domínguez H, Núńez MJ Parajó JC (2001) Food Chemistry 72: 145-171.

Naczk M, Shadiky F (2004) Journal of Chromatography A 1054: 95-11.
NATIONAL CHOLESTEROL ADUCATION PROGRAM (NCEP) EXPERT PANEL ON DETECTION, EVALUATION, AND TREATMENT OF HIGH BLOOD CHOLESTEROL IN ADULTS (ADULT TREATMENT PANEL III): Third Report of the National Cholesterol Aducation Program (NCEP) ExpertPanel on Detection, Evaluation, and Treatment of High Blood Cholesterol in Adults (Adult Treatment Panel III) (2002) final report. Circulation 106: 3143-3421.

Nevaz MA. Nawal NNA (1999) Clinical and Experimental Hypertension 21: 1297-1313.

Pérez MR, Gómez MG (2011) Endocrinologia Y Nutrición 58: 360-369.

Perez-Vizcaino F, Duarte J, Audriantshitohaina R (2006) Free Radical Research 40: 1054-1065.

Petersen KF, Shulman GI (2006) American Journal of Medicine 119: 10-16.

Potenza MV, Mechanick JI (2009) Nutrition and Clinical Practice 24: 560-577.

Prasain JK, Carlson SH, Wyss JM (2010) Maturitas 66: 163-164.

Procopiou M, Phillippe J (2005) Cerebrovascular Diseases 20: 2-8.

Rabe K, Lehrke M, Parhofer KG, Broedl UC (2008) Molecular Medicine 14: 741-751.

Rask-Madsen C, Domingues H, Ihlemann N (2003) Circulation 108: 1815-1821.

Reaven GM (1993) Annual Review of Medicine 44: 121-131.

Ritchie SA, Conell JMC (2007) Nutrition, Metabolism \& Cardiovascular Diseases 17: 319-326.

Russo C, Olivieri O, Girelly D, Faccini G, Zenari ML, Lombardi S, Corrocher R (1998) Journal of Hypertension 16: 1267-1271.

Ryo M, Nakamura T, Kihara S, Kumada M, Shibazaki S, Takahashi M, Nagai M, Matsuzawa Y, Funahashi T (2004) Circulation Journal 68: 975-981.

Rytting K (2005) Food, diet and obesity. CRC Press LLC, Holandsko.

Salamone LM, Fuerst T, Visser M, Kern M, Lang T, Dockrel M, Cauley J, Nevitt M, Tylavsky F, Lohman TG (2000) Journal of Applied Physiology 89: 345-352.

Salonen JT, Salonen R, Ihananen M, Parviainen M, Seppänen R, Kantola M, Seppänen K, Rauramaa R (1998) American Journal of Clinical Nutrition 48: 1226-1232.

Scott MG (2004) Journal of Clinica Endokrinology \& Metabolism 89: 2595-2600.

Shilpa NB, Tucker KL (2011) Clinica Chimica Acta 412: 1494-1914.

Sninčák M (2006) Artériová hypertenzia v staršom veku. TypoPress, Košice.

Stalicas CD (2007) Journal of Separation Science 30: 3268-3295.

Stevenson DE, Hurst RD (2007) Cellular and Molecular Life Sciences 64: 2900-2916.

Strazzulo P, Barbatto A, Siani A, Cappuccio FP, Versiero M, Schiattarella P, Russo O, Avallone S, della Valle E, Farinaro E (2008) Metabolism Clinical and Experimental 57: 355-361.

Subramanian N, Venkatesh P, Ganguli S, Sinkar VP (1999) Journal of Agriculture and Food Chemistry 47: 2571-2578. 
Surh YJ (2002) Food Chemistry and Toxicology 40: 1091-1097.

Surh YJ, Chun KS, Cha HH, Han SS, Keum YS, Park KK, Lee SS (2001) Mutation Research, 480: 243-268.

Svačina Š, Bretšnajdrová A (2008) Klinická dietologie. Grada, Praha.

Taesun P, Yunyung K (2011) Antiobesity Drug Discovery and Development 1: 14-20.

Tai K, Need AG, Horowitz M, Chapman IM (2008) Nutrition 24: 279-285.

Tan CB (2007) Cardiovascular and Haematological Disorgers-Drug Targets 7: 99-108.

Thielecke F, Boschmann M (2009) Phytochemistry 70: 11-23.
Tkáč I (2006) Cardiology 15: 305-310.

Tsuda T, Ueno Y, Yoshikawa T, Kojo H, Osawa T (2006) Biochemical Pharmacology 71: 1184-1197.

Van de Vijver LPL, Van den Bosch LMC, Van den Brandt PA, Goldbohm RA (2009) European journal of Clinical Nutrition 63: 31-38.

Van Horn L, McCoin M, Kris-Etherton PM, Burke F, Carson JA, Champagne CM, Karmally W, Sikand G (2008) Journal of the American Dietetic Association 108: 287-331.

Wen Z, Kilalle S, McGettigan P, Feely J (1996) Irish Journal of Medical Sciences 165: 210-212. 